\title{
Membrane Extraction of Chromium(VI) by Tri-n-Octylamine during Electrodialysis
}

\author{
Tatiana Sadyrbaeva, \\ Institute of Inorganic Chemistry of Riga Technical University
}

\begin{abstract}
A new process for chromium(VI) removal from aqueous solutions is presented. The process includes the transport of chromium(VI) anionic complexes from chloride acidic solutions through bulk liquid membranes at galvanostatic electrodialysis. Solutions of tri-n-octylamine with admixtures of $\mathrm{di}(2$ ethylhexyl)phosphoric acid in 1,2-dichloroethane have been used as the liquid membranes. Effects of current density, chromium(VI) and acid concentration in the feed solution, carrier and admixture concentration in the liquid membrane, type of acid in the stripping solution are studied, and optimum conditions are determined. Practically complete removal of chromium(VI) from the feed solution containing $0.01 \mathrm{~mol} / \mathrm{L} \quad \mathrm{K}_{2} \mathrm{Cr}_{2} \mathrm{O}_{7}$ is achieved during 1.0 - 4.0 hours of electrodialysis. Maximum stripping degree of $\sim 90 \%$ is obtained under optimum conditions. A possibility of effective single-stage removal of chromium(VI) into dilute solutions of hydrochloric, sulphuric, perchloric, phosphoric acids and water is demonstrated.
\end{abstract}

Keywords - Chromium(VI), electrodialysis, liquid membrane, tri-n-octylamine.

\section{INTRODUCTION}

Chromium finds extensive use in the industry due to its hardness, resistance to corrosion and magnetic properties. Chromium is an important alloying material for steel; it is used for surface coating and in refractory materials [1]. Chromium(VI) is one of the highly toxic, carcinogenic and mutagenic heavy metals; therefore, the removal of this metal ion from the effluents and waste waters is a problem of great significance. Chromium(VI) exists in the aqueous solutions as various anionic species; therefore, solvent extraction with anion exchange extractants can be used for the removal of chromium(VI) from aqueous solutions [2]. The liquid membrane technology has a great potential for the removal of heavy metals from aqueous dilute solutions [3]. The liquid membrane is a layer of an organic solvent separating two aqueous solutions. Liquid membranes offer a lot of advantages over solvent extraction, such as combination of extraction and stripping processes into a single stage, more effective separation of elements with similar properties and small amounts of extractants. Removal of chromium(VI) using bulk [4], supported [5], emulsion [6, 7] and polymer [8] liquid membranes containing tri-n-octylamine (TOA) is reported in the literature.

The electric field gradient is a driving force of the membrane extraction process during electrodialysis. The first study on the electrodialysis of liquid membranes was conducted by Purin [9], who concentrated rhenium from industrial solutions. Application of a direct electric field significantly intensifies the transport of metal ions through the liquid membranes and facilitates the stripping of metals from organic solutions of tertiary amine salts [10]. It has been demonstrated by the author previously that tri- $n$-octylamine - based liquid membranes ensure an effective separation of palladium(II) from macroadmixtures of copper(II), nickel(II) and iron(III) [11], platinum(IV) from iron(III) [12] and nickel [13] extracting from hydrochloric acid solutions, as well as separation of cobalt(II) from nickel(II) [14] extracting from hydrochloric acid solutions during electrodialysis. The aim of the present research is to study the membrane extraction of chromium(VI) from hydrochloric acid solutions by bulk liquid membranes containing TOA during galvanostatic electrodialysis.

\section{EXPERIMENTAL PART}

\section{A. Instrumentation}

The experiments were carried out in a five-compartment Teflon electrodialysis cell in the system:

\begin{tabular}{l|c|c|c|c}
$(-) \mathrm{Pt}$ & $\mathrm{K}_{2} \mathrm{Cr}_{2} \mathrm{O}_{7}$ & Liquid & $\mathrm{HCl}$ & $\mathrm{Pt}(+)$ \\
$\mathrm{H}_{2} \mathrm{SO}_{4}$ & $\mathrm{HCl}$ & membrane & & $\mathrm{H}_{2} \mathrm{SO}_{4}$
\end{tabular}

The liquid membrane (thickness of $0.3 \mathrm{~cm}$, volume of $2.5 \mathrm{~cm}^{3}$, surface area of $7.1 \mathrm{~cm}^{2}$ ) was separated from the aqueous solutions by two vertical cellophane films. The electrode compartments containing $0.15 \mathrm{M} \mathrm{H}_{2} \mathrm{SO}_{4}$ solutions (volume $17 \mathrm{~cm}^{3}$ ) were separated from the feed and strip solutions (volume $13 \mathrm{~cm}^{3}$ ) by the solid cation exchange membranes MK-40. The cellophane films and the solid membranes were soaked in water for more than $24 \mathrm{~h}$ before use. The solutions were not agitated. The direct electric current was supplied to the plane platinum electrodes $(2.4 \mathrm{~cm} \times 1.5 \mathrm{~cm})$. Potentiostat $\Pi-5827 \mathrm{M}$ was used as a current source. Voltage was measured by a digital voltmeter. Concentration of chromium(VI) in the aqueous solutions was determined spectrophotometrically by characteristic absorption peak for $\left[\mathrm{Cr}_{2} \mathrm{O}_{7}\right]^{2-}$ ions in the acidic solutions at $442 \mathrm{~nm}$ [15]. UV-Vis spectrophotometer СФ-46 was used for the analysis of metal ions.

\section{B. Reagents and Materials}

The solutions of tri- $n$-octylamine (pure grade) with the admixtures of di(2-ethylhexyl)phosphoric (D2EHPA technical grade, contents of the main substance $\sim 63 \%$ ) in 1,2-dichloroethane were used as the liquid membranes. They contained usually 0.1 or $0.2 \mathrm{M}$ TOA and 10 vol.\% D2EHPA. The feed solution was prepared by dissolving of $\mathrm{K}_{2} \mathrm{Cr}_{2} \mathrm{O}_{7}$ (analytically pure grade) in the hydrochloric acid of appropriate concentration, as a rule, $0.1 \mathrm{M} \mathrm{HCl}$. The initial concentration of 
$\mathrm{Cr}(\mathrm{VI})$ ions was usually $0.01 \mathrm{~mol} / \mathrm{L}$. Reagents of pro-analysis grade were used without further purification.

\section{RESULTS AND DISCUSSION}

Chromium(VI) can exist in the aqueous solutions in different anionic forms. The following general equilibrium is implemented in chromium(VI) solutions [16]:

$$
\mathrm{Cr}_{2} \mathrm{O}_{7}{ }^{2-}+\mathrm{H}_{2} \mathrm{O} \leftrightarrow 2 \mathrm{HCrO}_{4}^{-} \leftrightarrow 2 \mathrm{H}^{+}+2 \mathrm{CrO}_{4}{ }^{2-}
$$

$\mathrm{CrO}_{4}{ }^{2-}$ anions prevail in basic or weakly acidic media, while $\mathrm{HCrO}_{4}{ }^{-}$and $\mathrm{Cr}_{2} \mathrm{O}_{7}{ }^{2-}$ ions coexist in acidic solutions. Bichromate ions convert into $\mathrm{HCrO}_{4}^{-}$anions at a total chromium(VI) concentration lower than $(1.26-1.74) \times 10^{-2} \mathrm{~mol} / \mathrm{L}$ [17]. Thus, in this study chromium(VI) exists mainly as $\mathrm{HCrO}_{4}^{-}$anions.

Chromium(VI) ions are extracted by TOA due to the interfacial anion exchange mechanism. The amine first reacts with hydrochloric acid to form tri-n-octylammonium chloride:

$$
\begin{aligned}
& \mathrm{H}_{(\text {a) }}^{+}+\mathrm{Cl}^{-}{ }_{(\mathrm{a})}+\mathrm{R}_{3} \mathrm{~N}_{(\mathrm{o})} \leftrightarrow \mathrm{R}_{3} \mathrm{NH}^{+} \mathrm{Cl}^{-}{ }_{(\mathrm{o})}
\end{aligned}
$$

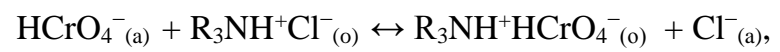

where $\mathrm{R}_{3} \mathrm{~N}$ is tri-n-octylamine, a - aqueous phase, o-organic phase.

In the presence of D2EHPA in the liquid membrane, an ion pair is formed, which consists of an organic cation and an organic anion [18]:

$$
\mathrm{R}_{3} \mathrm{~N}_{(\mathrm{o})}+\mathrm{HA}_{(\mathrm{o})} \leftrightarrow \mathrm{R}_{3} \mathrm{NH}^{+} \mathrm{A}_{(\mathrm{o})}^{-},
$$

where HA is di(2-ethylhexyl)phosphoric acid.

Chromium(VI) ions are extracted by TOA in the presence of D2EHPA due to the following mechanism:

$\mathrm{HCrO}_{4}^{-}(\mathrm{a})+\mathrm{R}_{3} \mathrm{NH}^{+} \mathrm{A}_{(\text {o) }}^{-} \leftrightarrow \mathrm{R}_{3} \mathrm{NH}^{+} \mathrm{HCrO}_{4}^{-}{ }_{(\mathrm{o})}+\mathrm{A}_{(\mathrm{o})}^{-}$

$\mathrm{Cr}(\mathrm{VI})$ ions are transferred by diffusion to the interface feed solution / liquid membrane and interact with the carrier to form ionic associates (reactions 3,5). The transported compounds diffuse through the liquid membrane layer and dissociate at the polarized 1,2-dichloroethane / water interface (reverse reactions $3,5)$. The carrier's molecules return back according to their concentration gradient. $\mathrm{HCrO}_{4}{ }^{-}$anions, appearing in the liquid membrane as a result of partial dissociation of the extractable complexes, are transferred through the organic layer owing to electromigration. Chloride anions permeate across the liquid membrane in the same direction as $\mathrm{Cr}(\mathrm{VI})$ ions; thus, a transport mechanism is chromium-chloride cotransport.

In the presence of the cation exchange carrier D2EHPA, hydrogen ions from the strip hydrochloric acid solution interact with the carrier at the interface liquid membrane / strip solution according to reaction 6 and are transferred across the liquid membrane into the feed solution in the direction opposite to $\mathrm{HCrO}_{4}^{-}$transport:

$$
\mathrm{H}^{+}(\mathrm{a})+\mathrm{R}_{3} \mathrm{NH}^{+} \mathrm{A}_{(\mathrm{o})}^{-} \leftrightarrow \mathrm{HA}_{(\mathrm{o})}+\mathrm{R}_{3} \mathrm{NH}^{+}{ }_{(\mathrm{o})}
$$

At the interface feed solution / liquid membrane, reaction 6 goes from right to left.
Hydrogen ions are transferred from the feed solution across the solid cation exchange membrane into the cathode compartment as well as are transported from anode compartment into the strip solution owing to electroneutrality condition. Redox reactions occurring at the electrodes are coupled to the transmembrane ion transport. Hydrogen evolution occurs at the cathode, and oxygen evolution occurs at the platinum anode in the sulphuric acid solutions:

$$
\begin{aligned}
& 2 \mathrm{H}^{+}+2 \mathrm{e}^{-} \rightarrow \mathrm{H}_{2} \uparrow \\
& 2 \mathrm{H}_{2} \mathrm{O} \rightarrow \mathrm{O}_{2} \uparrow+4 \mathrm{H}^{+}+4 \mathrm{e}^{-}
\end{aligned}
$$

It was found out in the preliminary experiments that the transfer of chromium(VI) anions into the strip solution practically was not observed without the electric field application. The imposition of an electric field allows to intensify chromium(VI) extraction from the feed solution and to transfer $\mathrm{HCrO}_{4}^{-}$anions through the liquid membranes. The increase of the current density results in an increase of the chromium(VI) anion transport rate (Table 1). Practically complete $(>99 \%)$ removal of the metal from the feed solution by the liquid membranes containing individual TOA solutions as well as TOA with admixtures of D2EHPA can be achieved during $1 \mathrm{~h}-4 \mathrm{~h}$ of electrodialysis depending on the current density. The maximum stripping degree of $89 \%$ is achieved at the current density of $10.6 \mathrm{~mA} / \mathrm{cm}^{2}$.

The chromium(VI) transport rate depends on the acidity of the feed hydrochloric solution. The highest chromium(VI) flux was achieved in the system with $0.01 \mathrm{M} \mathrm{HCl}$ in the feed solution (Fig. 1, line •). Transport rate is directly proportional to the current density up to $12.7 \mathrm{~mA} / \mathrm{cm}^{2}$. An increase in the $\mathrm{HCl}$ content in the feed solution from $0.01 \mathrm{M}$ to $0.1 \mathrm{M}$ leads to a decrease in the metal transport rate (Fig. 1, curves $\downarrow$ and $\mathbf{\Delta}$ ). It is presumed to occur due to the chloride ion transfer intensification through the liquid membrane, resulting in the current efficiency decrease for $\mathrm{Cr}(\mathrm{VI})$ anions.

TABLE 1

EFFECT OF CURRENT DENSITY UPON THE CHROMIUM(VI) EXTRACTION DEGREE E, STRIPPING DEGREE S AND FLUX J

$\left(\mathrm{C}_{\mathrm{Cr}}=0.01 \mathrm{~mol} / \mathrm{L} ; \mathrm{C}_{\mathrm{D} 2 \mathrm{EHPA}}=10 \mathrm{vol} \%\right.$; strip solution $\left.-0.1 \mathrm{M} \mathrm{HCl}\right)$

\begin{tabular}{|c|c|c|c|c|c|c|c|}
\hline $\mathrm{i}, \mathrm{mA} / \mathrm{cm}^{2}$ & $\mathrm{t}, \mathrm{min}$ & $\mathrm{C}_{\mathrm{TOA}}, \mathrm{M}$ & $\mathrm{C}_{\mathrm{HCl}}, \mathrm{M}$ & \multicolumn{2}{|c|}{$\mathrm{E}_{\mathrm{Cr}}$} & $\mathrm{S}_{\mathrm{Cr}}$ & \multirow{2}{*}{$\mathrm{J}_{\mathrm{Cr}} \cdot 10^{5}}$, \\
\cline { 5 - 6 } & & & & \multicolumn{2}{|c|}{$\%$} & $\mathrm{~mol} /\left(\mathrm{m}^{2} \mathrm{~s}\right)$ \\
\hline 0 & 120 & 0.1 & 0.1 & 25.7 & 0 & 0 \\
\hline 6.4 & 235 & 0.1 & 0.1 & 100 & 85 & 1.1 \\
\hline 8.5 & 159 & 0.1 & 0.1 & 99.8 & 80 & 1.5 \\
\hline 10.6 & 168 & 0.1 & 0.1 & 99.6 & 89 & 1.6 \\
\hline 12.7 & 132 & 0.1 & 0.1 & 99.2 & 85 & 1.9 \\
\hline 14.9 & 122 & 0.1 & 0.1 & 99.3 & 83 & 2.0 \\
\hline 4.2 & 173 & 0.2 & 0.01 & 99.8 & 85 & 1.5 \\
\hline 6.4 & 109 & 0.2 & 0.01 & 99.7 & 84 & 2.3 \\
\hline 8.5 & 86 & 0.2 & 0.01 & 99.4 & 86 & 3.0 \\
\hline 10.6 & 73 & 0.2 & 0.01 & 99.0 & 84 & 3.5 \\
\hline 12.7 & 53 & 0.2 & 0.01 & 98.4 & 80 & 4.5 \\
\hline
\end{tabular}




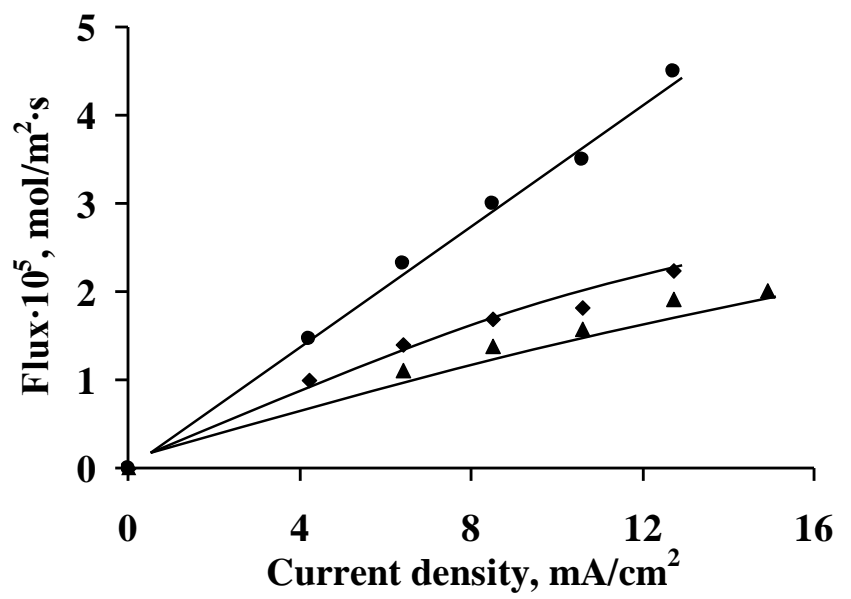

Fig. 1. Dependence of chromium(VI) flux in the strip solution on current density for various membrane systems. $\mathrm{c}_{\mathrm{TOA}}(\mathrm{M})=0.2(\bullet, \bullet)$; $0.1(\boldsymbol{\Delta}) ; \mathrm{c}_{\text {D2EHPA }}($ vol. $\%)=10(\bullet, \boldsymbol{\Delta}) ; 0(\bullet) ; \mathrm{c}_{\mathrm{HCl}}(\mathrm{M})=0.01(\bullet)$; $0.1(\diamond, \mathbf{\Delta})$

The duration of galvanostatic electrodialysis is limited as a rule by an abrupt increase of voltage within $1.0 \mathrm{~h}-4 \mathrm{~h}$ of electrodialysis depending on the current density, acidity of the feed solution and composition of the liquid membrane (Fig. 2). It was found out that the decrease of the electrical conductivity of the membrane system corresponded to a nearly complete $(\geq 99 \%)$ extraction of chromium(VI) from the feed solution (Table 1). The voltage increase is connected with desalination of the feed solution as a result of chromium(VI) anion and chloride ion extraction into the liquid membrane and hydrogen ion and $\mathrm{K}^{+}$cation transfer through the solid cation exchange membrane into the cathode compartment. Thus, the shape of the voltage - time diagram can be used for evaluating the removal completeness. At the same current density, desalination of the feed solution and the rise in voltage occur earlier in case of low $(0.01 \mathrm{M})$ hydrochloric acid concentration in the feed solution (Fig. 2, line $\circ$ ). Electrodialysis in the systems containing individual TOA solutions in the liquid membranes is characterized by a relatively high initial voltage (lines $\boldsymbol{\Delta}$ and $\boldsymbol{\bullet}$ ). The initial voltage decrease is connected with the rise of the total concentration of ions in the liquid membrane due to the extraction of hydrochloric acid and chromium(VI) ions by the carrier. The following increase in voltage is determined by desalination of the feed solution.

The kinetics of chromium(VI) transport through the liquid membranes containing $0.1 \mathrm{M}$ TOA and 10 vol.\% D2EHPA is presented in Fig. 3. Practically complete extraction of metal ions from the feed solution containing $0.01 \mathrm{~mol} / \mathrm{L} \mathrm{K}_{2} \mathrm{Cr}_{2} \mathrm{O}_{7}$ in $0.1 \mathrm{M} \mathrm{HCl}$ is achieved within $170 \mathrm{~min}$ of electrodialysis, about $90 \%$ of chromium(VI) is accumulated in the strip solution and $\sim 10 \%$ of the metal remains in the organic phase. The concentration of chromium(VI) anions in the strip solution is directly proportional to the process duration, whereas the metal content in the liquid membrane reaches its maximum value in 2 $\mathrm{h}$ of electrodialysis (curve $\bullet$ ). This time corresponds to the beginning of the sharp rise in voltage in the system.

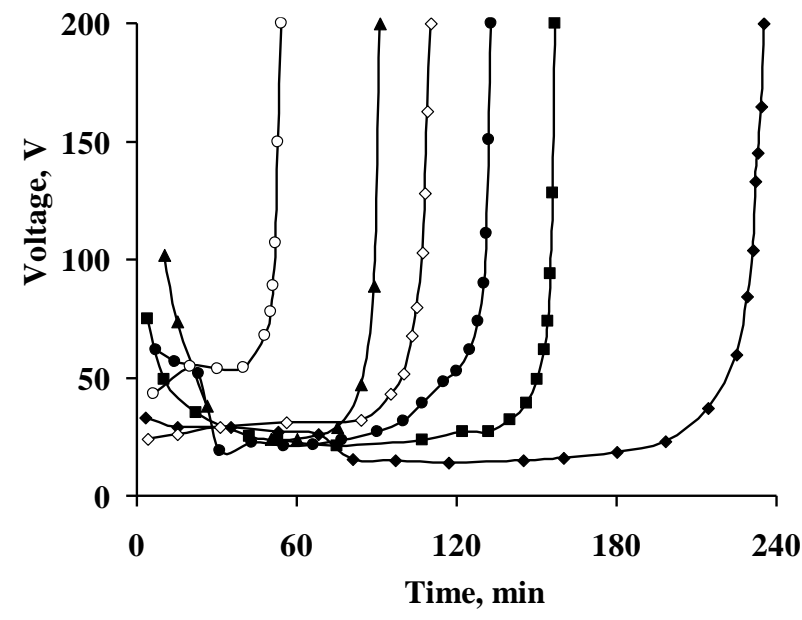

Fig. 2. Change in voltage during electrodialysis for various membrane systems. i $\left(\mathrm{mA} / \mathrm{cm}^{2}\right)=6.4(\diamond, \mathbf{m}, \diamond) ; 12.7(\circ, \boldsymbol{\Lambda}, \bullet)$; $\mathrm{c}_{\mathrm{HCl}}(\mathrm{M})=0.01(\mathrm{\circ}, \diamond) ; 0.1(\boldsymbol{\Delta}, \bullet, \boldsymbol{\bullet}, \bullet) ; \mathrm{c}_{\mathrm{TOA}}(\mathrm{M})=0.1(\bullet \bullet)$ $0.2(\circ, \boldsymbol{\Lambda}, \diamond, \boldsymbol{\square}) ; \mathrm{c}_{\text {D2EHPA }}($ vol. $\%)=0(\boldsymbol{\Delta}, \boldsymbol{\square}) ; 10(\circ, \diamond, \bullet, \diamond)$.

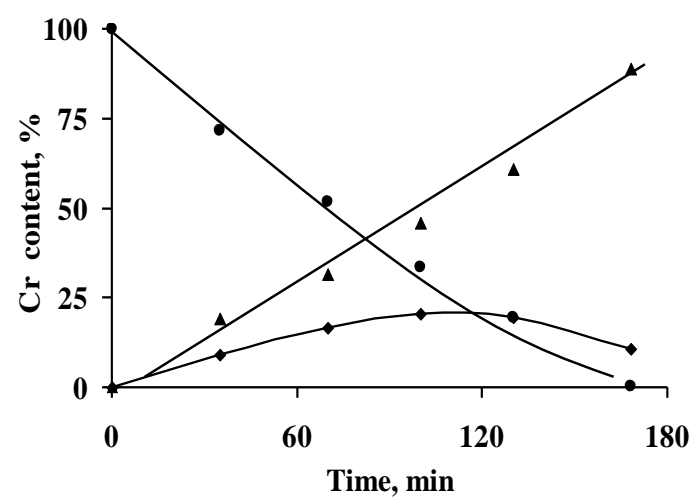

Fig. 3. Kinetics of chromium(VI) removal from the feed solution $(\bullet)$, accumulation in the liquid membrane $(\diamond)$ and in the strip solution $(\boldsymbol{\Delta})$ $\mathrm{i}=10.6 \mathrm{~mA} / \mathrm{cm}^{2} ; \mathrm{c}_{\mathrm{TOA}}=0.1 \mathrm{M} ; \mathrm{c}_{\mathrm{D} 2 \mathrm{EHPA}}=10 \mathrm{vol} . \% ; \mathrm{c}_{\mathrm{HCl}}=0.1 \mathrm{M}$.

It has been found out that the increase of chromium(VI) initial concentration in the feed solution from $4.3 \cdot 10^{-3} \mathrm{~mol} / \mathrm{L}$ to $9.9 \cdot 10^{-2} \mathrm{~mol} / \mathrm{L}$ leads to a rise of the metal transport rate into the strip solution, while the extraction and stripping degrees reduce (Table 2). The current efficiency calculated for $\mathrm{HCrO}_{4}^{-}$ transport is found to increase with the metal initial concentration rise, but does not exceed $10 \%$. The current is transferred through the liquid membranes containing D2EHPA mainly by chloride anions from the feed solution and hydrogen ions from the strip solution.

The acidity of the feed solution has been found to influence the chromium(VI) extraction efficiency. The increase of hydrochloric acid concentration in the feed solution from $0.05 \mathrm{M}$ to $0.5 \mathrm{M}-1.0 \mathrm{M}$ results in a significant decrease of the chromium(VI) transport rate as well as extraction and stripping degrees (Table 2). The increase of hydrochloric acid concentration leads to a rise of the chloride ion flux through the liquid membrane, resulting in the current efficiency 
decrease for chromium(VI) anions. The optimal acidity of the feed $\mathrm{K}_{2} \mathrm{Cr}_{2} \mathrm{O}_{7}$ solution is $0.05 \mathrm{M} \mathrm{HCl}$. More than $90 \%$ of chromium(VI) is extracted from the feed solution and sufficiently high stripping degree of $80 \%$ is achieved within $100 \mathrm{~min}$ of electrodialysis in this system.

The increase of TOA concentration in the liquid membrane from $0.05 \mathrm{M}$ to $0.3 \mathrm{M}-0.4 \mathrm{M}$, with the D2EHPA concentration being constant, leads to a some increase of the chromium(VI) extraction degree into the organic phase and transport rate into the strip solution (Table 2).

\section{TABLE 2}

EFFECT OF AQUEOUS SOLUTIONS AND LIQUID MEMBRANE COMPOSITION UPON THE CHROMIUM(VI) TRANSPORT $\left(\mathrm{i}=10.6 \mathrm{~mA} / \mathrm{cm}^{2} ; \mathrm{t}=100 \mathrm{~min} ; \mathrm{C}_{\mathrm{D} 2 \mathrm{EHPA}}=10 \mathrm{vol} . \%\right)$

\begin{tabular}{|c|c|c|c|c|c|c|}
\hline $\mathrm{C}_{\mathrm{Cr}}$ & $\mathrm{C}_{\mathrm{HCl}}$ & $\mathrm{C}_{\mathrm{TOA}}$ & \multirow{2}{*}{$\begin{array}{c}\text { Strip } \\
\text { solution } \\
(\mathrm{C}=0.1 \mathrm{M})\end{array}$} & $\mathrm{E}_{\mathrm{Cr}}$ & $\mathrm{S}_{\mathrm{Cr}}$ & \multirow{2}{*}{$\begin{array}{c}\mathrm{J}_{\mathrm{Cr}} \cdot 10^{5} \\
\mathrm{~mol} /\left(\mathrm{m}^{2} \mathrm{~s}\right)\end{array}$} \\
\hline \multicolumn{3}{|c|}{$\mathrm{mol} / \mathrm{L}$} & & \multicolumn{2}{|c|}{$\%$} & \\
\hline $4.3 \cdot 10^{-3}$ & 0.1 & 0.2 & $\mathrm{HCl}$ & 80 & 59 & 0.8 \\
\hline 0.01 & 0.1 & 0.2 & $\mathrm{HCl}$ & 74 & 55 & 1.7 \\
\hline $4.9 \cdot 10^{-2}$ & 0.1 & 0.2 & $\mathrm{HCl}$ & 59 & 47 & 7.0 \\
\hline $9.9 \cdot 10^{-2}$ & 0.1 & 0.2 & $\mathrm{HCl}$ & 45 & 31 & 9.4 \\
\hline 0.01 & 0.05 & 0.2 & $\mathrm{HCl}$ & 92 & 80 & 2.4 \\
\hline 0.01 & 0.5 & 0.2 & $\mathrm{HCl}$ & 40 & 18 & 0.5 \\
\hline 0.01 & 1.0 & 0.2 & $\mathrm{HCl}$ & 38 & 21 & 0.6 \\
\hline 0.01 & 0.1 & 0.05 & $\mathrm{HCl}$ & 64 & 49 & 1.5 \\
\hline 0.01 & 0.1 & 0.1 & $\mathrm{HCl}$ & 66 & 46 & 1.4 \\
\hline 0.01 & 0.1 & 0.3 & $\mathrm{HCl}$ & 80 & 55 & 1.7 \\
\hline 0.01 & 0.1 & 0.4 & $\mathrm{HCl}$ & 80 & 55 & 1.7 \\
\hline 0.01 & 0.1 & 0.1 & $\mathrm{H}_{2} \mathrm{O}$ & 74 & 73 & 2.2 \\
\hline 0.01 & 0.1 & 0.1 & $\mathrm{H}_{3} \mathrm{PO}_{4}$ & 70 & 55 & 1.7 \\
\hline 0.01 & 0.1 & 0.1 & $\mathrm{H}_{2} \mathrm{SO}_{4}$ & 71 & 49 & 1.5 \\
\hline 0.01 & 0.1 & 0.1 & $\mathrm{HclO}_{4}$ & 70 & 48 & 1.5 \\
\hline
\end{tabular}

The electrical conductivity of the membrane system is determined usually by the composition of the liquid membrane. The increase of TOA concentration in the organic phase from $0.05 \mathrm{M}$ to $0.4 \mathrm{M}$ leads to a rise of the electrical conductivity and to a decrease of the initial voltage of galvanostatic electrodialysis (Fig. 4, curves $\square$ and $\downarrow$ ). It should be noted that the storage time of the liquid membrane solution significantly influences the kinetics of chromium(VI) transport. A sharp increase of voltage occurs within an hour of electroialysis, and practically complete $(\approx 99 \%$ ) removal of chromium(VI) from the feed solution is achieved at a current density of $10.6 \mathrm{~mA} / \mathrm{cm}^{2}$ when $0.4 \mathrm{M}$ TOA solution is used immediately after preparation (Fig. 4, curve $\bullet$ ). Initial voltage in the system is somewhat lower, voltage changes insignificantly during electrodialysis, and extraction degree reduces $(\approx 80 \%$ within $100 \mathrm{~min}$ ) when the liquid membrane is used after 1 day of storage (Fig. 4, curve $\$$ ). Negative effect of the storage time on the transport properties of the liquid membranes can be attributed to the formation of the quaternary ammonium salt in the organic phase as a result of TOA interaction with 1,2dichloroethane [19]:

$$
\mathrm{R}_{3} \mathrm{~N}+\mathrm{CH}_{2} \mathrm{Cl}-\mathrm{CH}_{2} \mathrm{Cl} \rightarrow\left[\mathrm{R}_{3} \mathrm{NCH}=\mathrm{CH}_{2}\right]^{+} \mathrm{Cl}^{-}+\mathrm{HCl}
$$

The liquid membranes were used in the experiments within $0-3$ days after preparation.

Electrodialysis in the system containing individual TOA solution is characterized by a rather high initial voltage (Fig. 4, curve $\circ$ ). The addition of 40 vol.\% D2EHPA in the organic phase with the TOA concentration being constant decreases the voltage of galvanostatic electrodialysis (curve $\diamond$ ), however, leads to some reduction of the $\mathrm{Cr}(\mathrm{VI})$

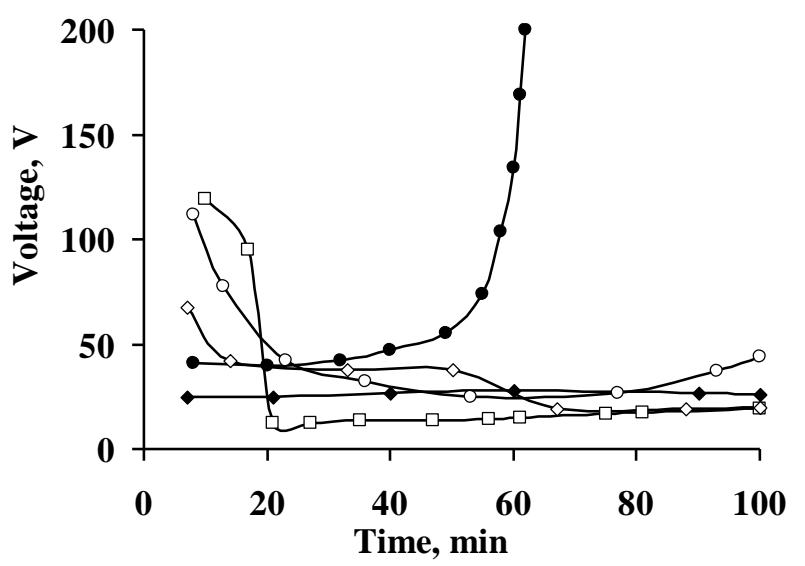

Fig. 4. Change in voltage during electrodialysis for various TOA and D2EHPA concentrations in the liquid membrane. $\mathrm{i}=10.6 \mathrm{~mA} / \mathrm{cm}^{2}$; $\mathrm{c}_{\mathrm{HCl}}=0.1 \mathrm{M} ; \mathrm{c}_{\mathrm{TOA}}(\mathrm{M})=0.05(\square) ; 0.2(\circ, \diamond) ; 0.4(\bullet, \bullet)$; $\mathrm{c}_{\text {D2EHPA }}($ vol. $\%)=0(0) ; 10(\square, \bullet, \diamond) ; 40(\diamond)$.

extraction, stripping degrees and flux. It is presumed to occur due to the hydrogen ion transfer intensification from the strip solution through the liquid membrane resulting in the current efficiency decrease for $\mathrm{HCrO}_{4}^{-}$ions. Liquid membranes containing TOA with admixtures of 10 vol.\% D2EHPA were commonly used in the experiments.

The influence of the strip solution composition on the chromium(VI) extraction rate is illustrated in Table 2. In contrast to traditional membrane extraction, the nature of mineral acid in the strip solution does not exert a considerable influence on the electrodialytic transport of metals. The transfer of chromium(VI) ions proceeds with an approximately equal rate into $0.1 \mathrm{M}$ solutions of phosphoric, sulphuric, perchloric and hydrochloric acids. The maximum chromium(VI) extraction and stripping degrees as well as transport rate are achieved in the system containing distilled water as the strip solution. It should be mentioned that electrodialysis in this system is characterized by a higher voltage if compared with acids solutions.

\section{CONCLUSIONS}

1. The liquid membranes containing individual tri-noctylamine solutions or tri-n-octylamine with admixtures of di(2-ethylhexyl)phosphoric acid in 1,2-dichloroethane ensure an extraction of chromium(VI) from $\mathrm{HCl}$ solutions into dilute solutions of hydrochloric, sulphuric, perchloric, phosphoric acids and water during galvanostatic electrodialysis.

2. The chromium(VI) transport rate increases as a rule as the current density, $\mathrm{K}_{2} \mathrm{Cr}_{2} \mathrm{O}_{7}$ initial concentration in the feed 
solution and TOA concentration in the organic phase increase.

3 . The rise of the feed solution acidity and the increase of di(2-ethylhexyl)phosphoric concentration in the liquid membrane exert some negative influence on the chromium(VI) flux.

4. Type of acid in the strip solution insignificantly affects the chromium(VI) transport rate. The maximum metal ion flux is achieved in the system containing distilled water as the strip solution.

5. By varying the ratio of the current, the time and the concentrations of the components, practically complete (>99.5\%) removal of chromium(VI) from the feed solution containing $0.01 \mathrm{~mol} / \mathrm{L} \mathrm{K}_{2} \mathrm{Cr}_{2} \mathrm{O}_{7}$ and the maximum stripping degree of $\sim 90 \%$ are achieved in the studied systems.

\section{REFERENCES}

[1] Lavrukhina, A.K., Yukina, L.V. Analytical Chemistry of Chromium, Nauka, Moscow, 1979, 219 p. (in Russian).

[2] Shmidt, V.S. Extraction with Amines, Atomizdat, Moscow, 1980, 264 p. (in Russian).

[3] Ivakhno, S.Yu., Yurtov, E.V. Membrane Extraction, VINITI, Moscow, 1990, 174 p. (in Russian).

[4] Sadoun, F., Hassaine-Sadi, F. Purification-concentration process. Studies on the transport mechanism of a chromium(VI)-sulfuric acid-trin-octylamine (TOA) - ammonium carbonate system, Desalination, 2004 vol 167, pp. 159-163. http://dx.doi.org/10.1016/j.desal.2004.06.125

[5] Chaudry, M.A., Ahmad, S., Malik, M.T. Supported liquid membrane technique applicability for removal of chromium from tannery wastes, Waste Management, 1998, vol. 17, N 4, pp. 211-218. http://dx.doi.org/10.1016/S0956-053X(97)10007-1

[6] Kumbasar, R.A. Selective separation of chromium(VI) from acidic solutions containing various metal ions through emulsion liquid membrane using trioctylamine as extractant, Separ. Purif. Technol., 2008 , vol. 64 , N 1, pp. 56-62. http://dx.doi.org/10.1016/j.seppur.2008.08.005

[7] Rajasimman, M., Karthic, P. Application of response surface methodology for the extraction of chromium(VI) by emulsion liquid membrane, J. Taiwan Instit. Chem. Engin., 2010, vol. 41, N 1, pp. 105-110.

http://dx.doi.org/10.1016/j.jtice.2009.04.010

[8] Kozlowski, C.A., Walkowiak, W. Removal of chromium(VI) from aqueous solutions by polymer inclusion membranes, Water Research., 2002, vol. 36, N 19, pp. 4870-4876.

http://dx.doi.org/10.1016/S0043-1354(02)00216-6
[9] Purin, B.A. Electrochemical Extraction as the Method of the Purification of Metals using Liquid Membranes, Izvestia AN LatvSSR, 1971, N 5, pp. 31-36 (in Russian).

[10] Purin, B.A. The Influence of an Electric Field on the Membrane Extraction of Substances. In: International Solvent Extraction Symposium, Moscow, Russia, June 21-27, 1998. Proceedings, Moscow, 1998, pp. 234-241.

[11] Sadyrbaeva, T. Zh., Purin, B. A. Palladium transfer and separation from iron and nonferrous metals at electrodialysis in systems containing liquid membranes, Latvijas ķīmijas žurnāls, 1993, N 3, pp. 301-308 (in Russian).

[12] Sadyrbaeva, T. Zh. Separation of Platinum(IV) and Iron(III) by Liquid Membranes under Electrodialysis Conditions, Russ. J. Appl. Chem., 2003, vol. 76, N 1, pp. 76-79. http://dx.doi.org/10.1023/A:1023343816916

[13] Sadyrbaeva, T.Zh. Membrane extraction of platinum(IV) by tri-noctylamine in the presence of nickel(II). Scientific Journal of Riga Technical University. Ser. Material Science and Applied Chemistry, 2007, vol. 15 , pp. 126-132.

[14] Sadyrbaeva, T.Zh. Separation of cobalt(II) and nickel(II) by liquid membranes during electrodialysis. Scientific Journal of Riga Technical University. Ser. Material Science and Applied Chemistry, 2013, vol. 27, pp. 56-60.

[15] Marchenko, Z. Photometric Determination of Elements, Mir, Moscow, 1971, 504 p. (in Russian).

[16] Gherasim, C.-V., Bourceanu, G., Olariu, R.-J., Arsene, C. A novel polymer inclusion membrane applied in chromium(VI) separation from aqueous solutions. J. Hazard. Mater., 2011, vol. 197, pp. 244-253. http://dx.doi.org/10.1016/j.jhazmat.2011.09.082

[17] Bhowal, A., Datta, S. Studies on transport mechanism of $\mathrm{Cr}(\mathrm{VI})$ extraction from acidic solutions using liquid surfactant membranes. J. Membr. Sci., 2001, vol. 188, N 1, pp. 1-8. http://dx.doi.org/10.1016/S0376-7388(00)00586-X

[18] Belova, V.V., Kholkin, A.I., Muhl, P. et al. A Study of an Extracting of Hexachloroplatinum and Tetrachloropalladium Acids with Salts of Tri- $n$ octylamine and Organic Acids. In: International Solvent Extraction Conference ISEC'88, Moscow, Russia, July 18-24, 1988. Moscow: Nauka, 1988, vol. 3, pp. 191-194.

[19] Popov, A. N., Timofeeva, S. K. Voltammetry of liquid membranes.VIII. n-trioctylamine salt solutions in 1,2-dichloroethane. Peculiarities of anion transfer, Izvestia AN LatvSSR, Ser. Khim.,1990, N 6, pp. 707-714 (in Russian).

Tatiana Sadyrbaeva graduated from the Latvian State University, Faculty of Chemistry (1984). She received Dr. Chem. degree (1993) from the Institute of Inorganic Chemistry of the Latvian Academy of Sciences. She is a Leading Researcher at the Laboratory of Electrochemistry of RTU Institute of Inorganic Chemistry.

Current and previous research interests include electrodialysis through liquid membranes, electrodeposition, separation of metals, liquid extraction.

E-mail: sadyrbaeva@hotmail.com.

Tatiana Sadirbajeva. Hroma(VI) membrānekstrakcija ar tri-n-oktilamīnu elektrodialīzes apstākḷos

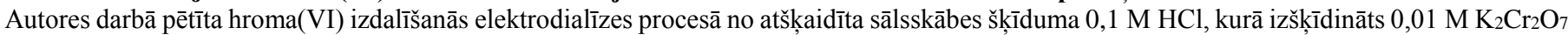
un kas satur šḳidras membrānas, kuras veido tri-n-oktilamīns ar di(2-etilheksil)fosforskābes piedevām. Pētījumā noskaidrots, ka šḳidrās membrānas, kas satur tri-n-oktilamīna šḳīdumu vai tri-n-oktilamīnu ar di(2-etilheksil)fosforskābes piedevām, nodrošina pilnīgu (> 99 \%) hroma(VI) anjonu izdalīšanos no izejas šḳīduma un to pārnesi atšķaidītos minerālskābju šķīidumos galvanostatiskās elektrodialīzes apstākḷos. Pētījuma rezultāti rāda, ka hronopotenciogrammu forma var kalpot par kritēriju hroma(VI) jonu izdalīšanās daudzuma noteikšanai no izejas šḳīdumiem. Noteikts, ka, paaugstinot strāvas blīvumu $\left(0 \mathrm{~mA} / \mathrm{cm}^{2}-12,7 \mathrm{~mA} / \mathrm{cm}^{2}\right)$ un palielinot metāla koncentrāciju izejas škīidumā no $4,3 \cdot 10^{-3} \mathrm{M}$ līdz $9,9 \cdot 10^{-2} \mathrm{M}$, pieaug hroma(VI) izdalīšanās pakāpe uztvērējšḳīdumā. Metāla koncentrācijas palielināšana izejas šḳīdumā rada hroma(VI) iznākuma pieaugumu atkarībā no strāvas. Tri-n-oktilamīna daudzuma izmaiṇa organiskajā fāzē no 0,05 M līdz 0,4 M maz ietekmē hroma(VI) transmembrānās pārneses ātrumu. Sālsskābes koncentrācijas palielināšana izejas šḳīdumā no 0,01 M līdz 1,0 M, kāā arī di(2-etilheksil)fosforskābes daudzuma palielināšana škidrās membrānās (0 tilp.\% - 40 tilp.\%) negatīvi ietekmē hroma(VI) anjonu pārneses ātrumu. Optimāls izejas škīiduma skābums ir 0,05 M HCl. Pētījumā konstatēts, ka skābes daba uztvērējškīdumā maz ietekmē hroma(VI) jonu plūsmu caur škidro membrānu. Noteikts, ka škidrās membrānas veic hroma(VI) jonu pārnesi atšķaidītos sālsskābes, sērskābes, perhlorskābes, fosforskābes škīīumos un ūdenī. Optimālajos apstākḷos sasniegta praktiski pilnīga $(>99,5 \%)$ hroma(VI) izdalīšana no izejas šķīduma, un metāla reekstrakcijas pakāpe uztvērējškīidumā sasniedz atuveni $90 \%$. 
Татьяна Садырбаева. Мембранная экстракция хрома(VI) три-н-октиламином в процессе электродиализа

Исследован процесс электродиализного извлечения хрома(VI) из раствора $0,01 \mathrm{M} \mathrm{K} 2 \mathrm{Cr}_{2} \mathrm{O}_{7}$ в 0,1 M $\mathrm{HCl}$ жидкими мембранами, содержащими три-н-октиламин с добавками ди(2-этилгексил)фосфорной кислоты в 1,2-дихлорэтане. Установлено, что изученные жидкие мембраны обеспечивают полное (>99\%) извлечение анионов хрома(VI) из исходного раствора в разбавленные растворы различных кислот в условиях гальваностатического электродиализа. Изучено влияние плотности тока, состава исходного и принимающего водных растворов и жидких мембран на скорость трансмембранного переноса ионов металла, определены оптимальные условия процесса. Показано, что скорость извлечения хрома(VI) возрастает при повышении плотности тока $\left(0\right.$ мA $/ \mathrm{cm}^{2}-12,7$ мА $\left./ \mathrm{cm}^{2}\right)$, увеличении исходной концентрации металла в отдающем солянокислом растворе $\left(4,3 \cdot 10^{-3}\right.$ моль/л $-9,9 \cdot 10^{-2}$ моль/л) и мало зависит от изменения концентрации три-н-октиламина в органической фазе $(0,05 \mathrm{M}-0,4 \mathrm{M})$. Увеличение концентрации соляной кислоты в исходном растворе $(0,01 \mathrm{M}-1,0 \mathrm{M})$ и повышение содержания Д2ЭГФК в жидкой мембране $(0$ об.\% - 40 об.\%) негативно влияют на скорость трансмембранного переноса ионов хрома(VI). Установлено, что скорость извлечения анионов хрома(VI) через жидкую мембрану в растворы $0,1 \mathrm{M}$ соляной, серной, хлорной и фосфорной кислот примерно одинакова, а наиболее высокая скорость переноса ионов металла получена при использовании в качестве принимающего раствора дистиллированной воды. Достигнутая в оптимальных условиях максимальная степень извлечения хрома(VI) из принимающего раствора составляет около $90 \%$ при полном (>99,5\%) извлечении метала из исходного раствора. 